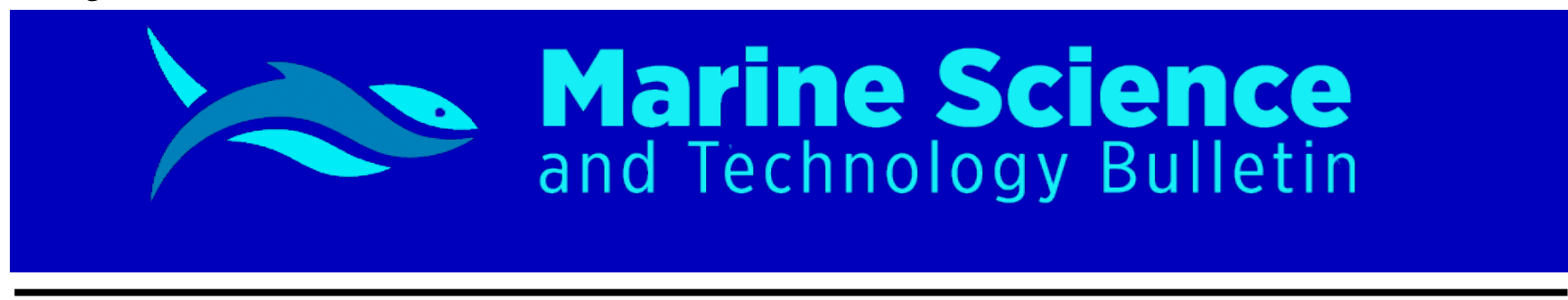

RESEARCH ARTICLE

\title{
Determination of growth conditions for Chlorella vulgaris
}

\section{İrem Deniz ${ }^{1^{*}}$}

${ }^{1}$ Manisa Celal Bayar University, Faculty of Engineering, Bioengineering Department, 45119, Muradiye, Manisa, Turkey

\begin{tabular}{|c|c|}
\hline A RTICLE I N FO & A B S T R A C T \\
\hline Article History: & \multirow{6}{*}{$\begin{array}{l}\text { Microalgae known as third generation technology for biofuel in nature are used as a } \\
\text { renewable bioenergy source. Microalgae and crop plants have common for the production } \\
\text { of organic compounds by using sunlight and carbon dioxide. In addition, microalgae are } \\
\text { capable of being reproducing in the whole year allowing the more product yield than those } \\
\text { of plants. Therefore, microalgae are more favorable feedstock since they have some } \\
\text { advantages such as photosynthetic efficiency, biomass productivity and oil content. In this }\end{array}$} \\
\hline Received: 09.04.2020 & \\
\hline Received in revised form: 12.05 .2020 & \\
\hline Accepted: 12.05 .2020 & \\
\hline Available online: 13.05 .2020 & \\
\hline Keywords: & \\
\hline Chlorella vulgaris & study, the most proper conditions for the growth of microalgae Chlorella vulgaris were \\
\hline Light & studied. After medium optimization, at $25^{\circ} \mathrm{C}$ and $\mathrm{pH}$ of 9 using 24 -hour-illuminating/day, \\
\hline Microalgae & the best growth conditions for C. vulgaris giving the maximum biomass productivity was \\
\hline & found to be $205 \mathrm{mg} / \mathrm{L}$ for 10 days. Determination of optimal microalgal growth conditions \\
\hline & may lead to an increase in the industrial applications of C. vulgaris. \\
\hline
\end{tabular}

Please cite this paper as follows:

Deniz, İ. (2020). Determination of growth conditions for Chlorella vulgaris. Marine Science and Technology Bulletin, 9(2): 114-117

\section{Introduction}

Microalgae are micrometer-sized aquatic organisms, generally in the range of $1-400 \mu \mathrm{m}$, and they are one of the oldest forms of life on the planet (Tijani et al., 2015). They have chlorophyll to be responsible for photosynthesis, their cells are covered with pigment-reproducing cells as well (Tan et al., 2018). Moreover, they account for approximately 50\% of the whole photosynthetic activity on Earth. Because, some microalgae have rapid growth such as double in number within hours, thus, having a short harvest time as less than 10 days (Bach and Chen, 2017).

\footnotetext{
* Corresponding author

E-mail address: iremdenz@gmail.com (İ. Deniz)
}

Microalgae particularly require optimum light, carbon dioxide, temperature, $\mathrm{pH}$ and nutrients to grow. While the light gives energy, carbon dioxide provides the carbon source for the production of biomass. Microalgae are able to produce different types of renewable biofuels such as biomethane with the anaerobic digestion process, biohydrogen, biodiesel with transesterification process and biochar production with pyrolysis process (Tan et al., 2018). Thus, microalgae can be accepted as an alternative and promising feedstock for energy production along with the overuse of fossil fuels. A progressive decline of resources of fossil fuels and an increase in climate change caused an obligatory situation to search for a renewable and sustainable energy source. Therefore, biofuels are 
considered as the best choice for that purpose (Jankowska et al., 2017). The fossil fuel energy is approximately $78.3 \%$ of the whole global energy consumption. Moreover, fossil fuel is a great contributor to $\mathrm{CO}_{2}$ emissions which are directly linked to global warming. Biodiesel is a clean-burning fuel and is obtained from plants such as soybeans, oil palms, jatropha and microalgae (Elrayies, 2018). The development stages of biofuels are classified into three generations in terms of their feedstock. The first generation of biofuels is obtained from food crops such as sugar cane, sugar beets, rapeseed, soybeans, oil palms and corn. However, the undesirable competition had occurred between food and fuel in time. This is due to the place intended for the production of food that was shifted to the production of food crops used for biofuels. The second generation biofuels are obtained from lignocellulosic agriculture, forest residues and non-food crop feedstocks which also termed as energy crops such as jatropha and pongamia. However, some deficiencies had been occurred such as low productivity of biomass, need for excess water and arable land, and also low energy required pretreatments. In recent years, a new biofuel generation had been appeared and known as the third generation biofuels which are obtained from microalgae. Microalgae culture as feedstock has more advantages compared that the second generation needs the more land, such as having high growth rate, the need for less amount of water for the growth as compared to terrestrial crops, having a high photosynthetic efficiency; having more oil productivity (Faried et al., 2017; Jankowska et al., 2017; Elrayies, 2018). In this study, the proper growth conditions of Chlorella vulgaris was investigated.

\section{Materials and Methods}

\section{Microalgae}

Chlorella vulgaris was provided by courtesy of Prof. Dr. Meltem Conk Dalay from Ege University Bioengineering Department, Turkey. The strain was preserved in the BG11 medium which has composition as follow: $\mathrm{NaNO}_{3}(1.5 \mathrm{~g} / \mathrm{L})$, $\mathrm{K}_{2} \mathrm{HPO}_{4} \cdot 3 \mathrm{H}_{2} \mathrm{O} \quad(0.04 \mathrm{~g} / \mathrm{L}), \quad \mathrm{MgSO}_{4} \cdot 7 \mathrm{H}_{2} \mathrm{O} \quad(0.075 \mathrm{~g} / \mathrm{L})$, $\mathrm{CaCl}_{2} \cdot 2 \mathrm{H}_{2} \mathrm{O}(0.036 \mathrm{~g} / \mathrm{L}), \mathrm{Na}_{2} \mathrm{CO}_{3}(0.02 \mathrm{~g} / \mathrm{L})$, citric acid $(0.006$ $\mathrm{g} / \mathrm{L})$, Ferric ammonium citrate $(0.006 \mathrm{~g} / \mathrm{L})$, EDTA (0.001 g/L), and $\mathrm{A} 5+$ Consolation $(1 \mathrm{~mL} / \mathrm{L})$ that consists of $\mathrm{H}_{3} \mathrm{BO}_{3}(2.86$ $\mathrm{g} / \mathrm{L}), \quad \mathrm{MnCl}_{2} \cdot \mathrm{H}_{2} \mathrm{O} \quad(1.81 \mathrm{~g} / \mathrm{L}), \quad \mathrm{ZnSO}_{4} \cdot 7 \mathrm{H}_{2} \mathrm{O} \quad(0.222 \mathrm{~g} / \mathrm{L})$, $\mathrm{CuSO}_{4} \cdot 5 \mathrm{H}_{2} \mathrm{O}(0.079 \mathrm{~g} / \mathrm{L}), \mathrm{Na}_{2} \mathrm{MoO}_{4} \cdot 2 \mathrm{H}_{2} \mathrm{O}(0.390 \mathrm{~g} / \mathrm{L})$ and $\mathrm{Co}\left(\mathrm{NO}_{3}\right)_{2} \cdot 6 \mathrm{H}_{2} \mathrm{O}(0.049 \mathrm{~g} / \mathrm{L})$ (Suthar and Verma, 2018). The BG11 medium was used as a growth medium in each experimental set-ups.

\section{Medium Optimization in Erlenmeyer Flasks}

Obtaining the most proper growth conditions was performed with $100 \mathrm{~mL}$ of BG11 medium within $250 \mathrm{~mL}$ of Erlenmeyer flasks in shaker-incubator (Microtest, Turkey). The different range of $\mathrm{pH}(5,7,9)$, temperature $\left(25,35,45^{\circ} \mathrm{C}\right)$ and illumination period $(24 \mathrm{~h}$ light/day, 12h-dark-and-12-h light/day, 24 h dark/day) were used using one variable at a time method. Microalgal cell biomass was separated from the medium by centrifugation at $5000 \mathrm{rpm}$ for $15 \mathrm{~min}$. Dry cell weight was used as a marker for biomass production.

\section{Analysis}

Microalgal cell biomass was separated from medium by centrifugation (Centurion, England). BG11 culture medium containing microalgae was centrifuged at $5000 \mathrm{rpm}$ for $15 \mathrm{~min}$, washed twice with distilled water then, the cell pellet was dried at $105^{\circ} \mathrm{C}$ until a constant weight was observed. Dry weight was measured by filtering a $10 \mathrm{~mL}$ of the culture by preweighted filters. After rinsed with ammonium bicarbonate, the filters were dried at $105^{\circ} \mathrm{C}$ overnight. Dry cell weight was used as a marker for biomass production.

For cell analysis, the culture broth was sampled daily and absorbance was recorded spectrophotometrically at $650 \mathrm{~nm}$.

\section{Results and Discussion}

\section{Optimization of pH}

In order to determine the optimum $\mathrm{pH}$ for $C$. vulgaris, the microalgae production has occurred in Erlenmeyer flasks in the range of $\mathrm{pH}$ of 5-9. In this study, the suitable value of $\mathrm{pH}$ with a maximum biomass concentration of $150 \mathrm{mg} / \mathrm{L}$ after 10 days for C. vulgaris was found as 9 . Once the $\mathrm{pH}$ goes up and the sufficient amount of $\mathrm{CO}_{2}$ is injected into the microalgal growth medium, $\mathrm{pH}$ would back to optimum and lead to an increase in the microalgal biomass. In another study, it was reported that the best growth $\mathrm{pH}$ of $C$. vulgaris was 9. It was interpreted that $\mathrm{H}^{+}$ion gradients control transport processes throughout the cellular membranes and perform the metabolic activities in the cytoplasm and organelles (Suthar and Verma, 2018).

\section{Optimization of Temperature}

The temperature range $\left(25,35,45^{\circ} \mathrm{C}\right)$ was used to determine the optimal temperature for $C$. vulgaris. The optimum temperature for the highest biomass concentration of $182 \mathrm{mg} / \mathrm{L}$ after 10 days was decided as $25^{\circ} \mathrm{C}$. The less growth has appeared at 35 and $45^{\circ} \mathrm{C}$. Microalgal growth rapidly decreased when the temperature exceeding the optimum temperature. Therefore, the growth did not occur above $35^{\circ} \mathrm{C}$. 
It was previously reported that the growth rates for $C$. vulgaris at $28^{\circ} \mathrm{C}$ and $25^{\circ} \mathrm{C}$ are not greatly different (Serra-Maia et al., 2016). It was also discovered that temperature below $30^{\circ} \mathrm{C}$ enhanced the solubility of $\mathrm{CO}_{2}$ in growth medium thus, dissolving the $\mathrm{CO}_{2}$ resulted in higher biomass production because of an increase in the growth rate of culture (Mathimani et al., 2017). Moreover, it was declared that the growth rate of C. vulgaris at $35^{\circ} \mathrm{C}$ exhibited a $17 \%$ decrease according to those at $30^{\circ} \mathrm{C}$ and further temperature caused a sharp interruption of microalgal growth and eventually cell deaths (Converti et al., 2009).

\section{Optimization of Illumination Period}

The microalgal growth was observed during different illumination conditions at $25^{\circ} \mathrm{C}$ and a $\mathrm{pH}$ value of 9 . Continuously illumination ( $24 \mathrm{~h}$ light/day) of the microalgal culture provided more rapid growth and higher biomass concentration of $205 \mathrm{mg} / \mathrm{L}$ for C. vulgaris after 10 days in this study. Previously, it was remarked that the lipid percent and biomass productivity were higher in 18:6 h light compared to $12 \mathrm{~h}$ and $24 \mathrm{~h}$ light when keeping the other conditions constant (Ebrahimian et al., 2014). However, it was also reported that there was no significant change in the lipid content of $C$. vulgaris when the dark cycle increases from $8 \mathrm{~h}$ to $12 \mathrm{~h}$ (Luangpipat and Chisti, 2017). In another study, it was shown that the best light:dark cycle for C. vulgaris was 16:8 h/day (Sasi, 2009). The cell growth at optimized conditions $\left(\mathrm{pH}=9,25^{\circ} \mathrm{C}\right.$ and continuous illumination) was shown in Figure 1.

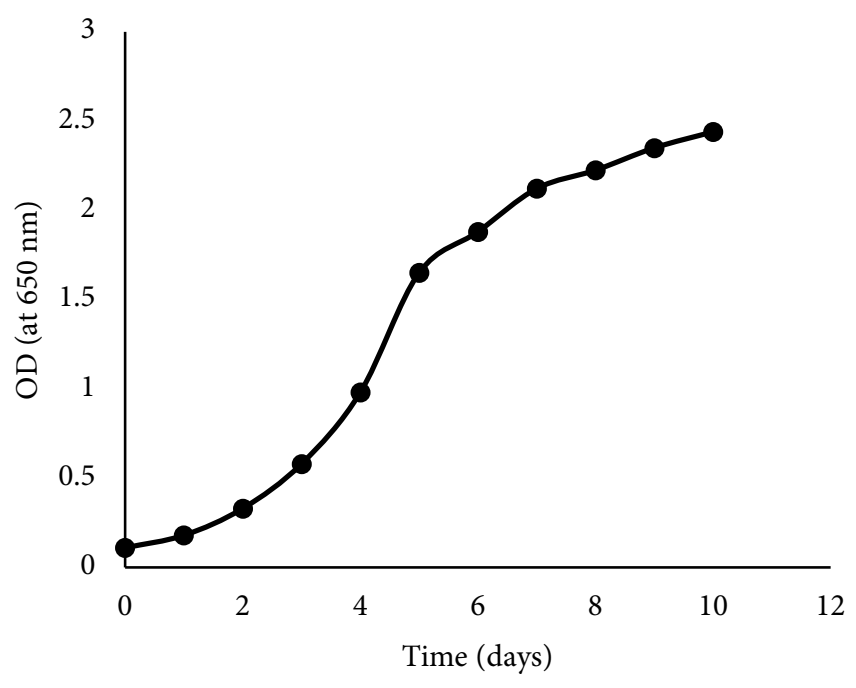

Figure 1. Cell concentration at optimized conditions

\section{Conclusion}

In this study, the best conditions with the highest biomass concentrations were determined to be $\mathrm{pH} 9,25^{\circ} \mathrm{C}$ and 24 hour light for the biomass growth of $C$. vulgaris regarding a biomass concentration of $205 \mathrm{mg} / \mathrm{L}$. Microalgae are one of the important sources for the production of biodiesel due to they possess high oil content and there is a limitation about keeping important places of plant-based oil such as safflower, canola and peanut in the food industry. This study focused on the biomass concentration of C. vulgaris providing its optimum growth conditions. In the future, the utilization of microalgae as a feedstock of renewable fuels is considered to increase.

\section{Acknowledgements}

This study was a part of a project funded by the Scientific Research Project Office of Manisa Celal Bayar University (Project No: 2018-114) and the author wishes to thank the office for their financial support.

\section{Compliance with Ethical Standards}

\section{Authors' Contributions}

Author ID designed, performed and managed statistical analyses of the study and wrote the manuscript. The author read and approved the final manuscript.

\section{Conflict of Interest}

The authors declare that there is no conflict of interest.

\section{Ethical Approval}

For this type of study, formal consent is not required.

\section{References}

Bach, Q. V. \& Chen, W. H. (2017). Pyrolysis characteristics and kinetics of microalgae via thermogravimetric analysis (TGA): A state-of-the-art review. Bioresource Technology, 246: 88-100. $\quad$ https://doi.org/10.1016/ j.biortech.2017.06.087

Converti, A., Casazza, A. A., Ortiz, E. Y., Perego, P. \& Del Borghi, M. (2009). Effect of temperature and nitrogen concentration on the growth and lipid content of Nannochloropsis oculata and Chlorella vulgaris for biodiesel production. Chemical Engineering and Processing: Process Intensification, 48(6): 1146-1151. https://doi.org/10.1590/1678-457x.13417

Ebrahimian, A., Kariminia, H. -R. \& Vosoughi, M. (2014). Lipid production in mixotrophic cultivation of Chlorella vulgaris in a mixture of primary and secondary municipal wastewater. Renewable Energy, 71: 502-508. https://doi.org/10.1016/j.renene.2014.05.031 
Elrayies, G. M. (2018). Microalgae: prospects for greener future buildings. Renewable and Sustainable Energy Reviews, 81: 1175-1191. https://doi.org/10.1016/j.rser.2017.08. $\underline{032}$

Faried, M., Samer, M., Abdelsalam, E., Yousef, R., Attia, Y. \& Ali, A. (2017). Biodiesel production from microalgae: Processes, technologies and recent advancements. Renewable and Sustainable Energy Reviews, 79: 893-913. https://doi.org/10.1016/j.rser.2017.05.199

Jankowska, E., Sahu, A. K. \& Oleskowicz-Popiel, P. (2017). Biogas from microalgae: Review on microalgae's cultivation, harvesting and pretreatment for anaerobic digestion. Renewable and Sustainable Energy Reviews, 75: 692-709. https://doi.org/10.1016/j.rser.2016.11.045

Luangpipat, T. \& Chisti, Y. (2017). Biomass and oil production by Chlorella vulgaris and four other microalgae-effects of salinity and other factors. Journal of Biotechnology, 257: 47-57. https://doi.org/10.3844/ojbsci.2015.260.267

Mathimani, T., Bhumathi, D., Ahamed, T. S., Dineshbabu, G., Deviram, G., Uma, L. \& Prabaharan, D. (2017). Semicontinuous outdoor cultivation and efficient harvesting of marine Chlorella vulgaris BDUG 91771 with minimum solid co-precipitation and high floc recovery for biodiesel. Energy Conversion and Management, 149: 13-25. https://doi.org/10.1016/ j.enconman.2017.06.077
Sasi, D. (2009). Biokinetic behaviour of Chlorella vulgaris in a continuously stirred bioreactor and a circulating loop photobioreactor. Master Thesis, University of Saskatchewan, Canada.

Serra-Maia, R., Bernard, O., Gonçalves, A., Bensalem, S. \& Lopes, F. (2016). Influence of temperature on Chlorella vulgaris growth and mortality rates in a photobioreactor. Algal Research, 18: 352-359. https://doi.org/10.1016/ j.algal.2016.06.016

Suthar, S. \& Verma, R. (2018). Production of Chlorella vulgaris under varying nutrient and abiotic conditions: A potential microalga for bioenergy feedstock. Process Safety and Environmental Protection, 113: 141-148. https://doi.org/10.1016/j.psep.2017.09.018

Tan, X. B., Lam, M. K., Uemura, Y., Lim, J. W., Wong, C. Y. \& Lee, K. T. (2018). Cultivation of microalgae for biodiesel production: A review on upstream and downstream processing. Chinese Journal of Chemical Engineering, 26(1): 17-30. https://doi.org/10.1016/j.cjche.2017.08. $\underline{010}$

Tijani, H., Abdullah, N. \& Yuzir, A. (2015). Integration of microalgae biomass in biomethanation systems. Renewable and Sustainable Energy Reviews, 52: 16101622. https://doi.org/10.1016/j.rser.2015.07.179 